\title{
Creative Accounting - Definition, Types, Purposes and Impact on United Nations' Sustainable Development Goals
}

\section{Ivan Gudev*}

\begin{abstract}
This article aims to define what is the essence of the so called "creative accounting", its purposes, types of creative accounting techniques and methods and how it relates to and impacts the United Nations' sustainable development goals (SDGs). Various definitions and characteristics are given to this phenomenon - different authors use variety of terms such as earnings management, income smoothing, creative accounting practices, aggressive accounting, cook the books, accounts manipulation, or window dressing. Irrespectively how it is called, it relates to one and the same thing presentation of companies' financial position, cash accounts, equity and earnings in a way that pursues specific personal objective. In most cases, this deliberate presentation is not fraudulent and does not violates the law or the relevant accounting standards, but breaks down the confidence in accounting profession and contradicts to the ethical principles of professional accountants. Specific attention is given to the relationship between accounting and sustainability and particularly, how creative accounting practices impact the achievement of United Nations' sustainable
\end{abstract}

development goals. Literature analysis and deliberations are presented on how creative accounting prevents the fair allocation of resources in economy and the damage it causes to society. This study does not pretend to explore in detail either the creative accounting, or the SDGs, but its essential objective is to create a basic overview on both phenomena and find intersection points between them. A lot of studies explore the relationship between accounting as a general term and UN' Sustainable Development Goals, but very few are focused specifically on the link between creative accounting and it's influence on the achievement of those goals.

Keywords: creative accounting, earnings management, UN's sustainable development goals

JEL: M40, M41, M48, H70, O10

\section{Introduction}

In order to measure the influence of creative accounting on the UN's sustainable development goals, first of all we need to identify the definition of creative accounting and how it relates to SDGs. Our analysis will be based on literature review on those topics, some empirical examples and conclusions based on the analyzed sources.

University of National and World Economy 


\section{Articles}

The contemporary role of professional accountants in reference to achieving the SDGs will be analyzed with specific accent on the negative side of their operation. Specific attention will be given to the ethical issues in accounting and how the temptation for achievement of personal goals can lead to failure in reaching global humanitarian objectives. On the positive side, Makarenko and Plastun (2017, p.5) cite Peter Bakker from the World Business Forum for Sustainable Development who states that "accountants are going to save the world". Accountants have the power to alleviate asymmetric information, appraise investment risks, create converged and integrated audit, provide and test standards of sustainability accounting, reporting and auditing within the new business model. He believes that "with specific professional skills and involvement in governance, risk management, business analysis, decision support, due diligence and anti-corruption activities, professional accountants today are reassessing their roles because of the SDGs and corporate sustainability". On the negative side, however, accountants can influence adversely the achievement of the SDGs in a way that they consciously do not follow the above procedures, striving to achieve personal or managerial objectives such as gaining bonuses, reaching company's targets and budgets, increase in company's stock price, etc., using the loopholes in accounting regulations.

\section{Definition and types of creative accounting and reasons behind its usage}

In the literature, there is a wide variety of definitions of creative accounting. Some sources and publications (Bragg, 2018) define the term as a toolset of unconventional methods and techniques to mutate the financial position and/or accounting profit/ loss of a business. Underlying incentives of managers to engage in such manipulations are to increase the level of their bonuses, convince lenders to release loans to the company or overstate its assets in the balance sheet in case of sale. Another widely spread motive to manipulate earnings is to reduce profit levels thus decreasing tax liabilities. The author points out some of the most common techniques for creative accounting such as the reduction of the monthly depreciation charge of an asset by unreasonable extension of assets' useful lives, increase in the salvage value of an asset again to reduce the periodic depreciation charge or decrease in the periodic accrual charge for the bad debt provisions. Oyedokun. (2018, p. 2) accentuates on the fact that the concept of creative accounting is not something new in the business world. However, he differentiates between manipulations based on loopholes in accounting regulations and standards and those based on accounting fraud and misuse. According to him, accounting practices that follow certain regulations and standards but deviate from what those regulations and standards are striving to achieve are referred to as creative accounting. CIMA Official Terminology (2005, p.64) formalizes the definition of creative accounting as "a form of accounting which, while complying with all regulations and practices, nevertheless gives a biased impression (generally favorable) of an entity's financial performance and position". To distinguish between creative accounting and accounting fraud, Jones (2011, pp.47) defines fraud with the usage of fictitious accounting transactions and those prohibited by generally accepted accounting principles (GAAP) that give assumption of fraud which becomes proved after administrative or court proceedings. He describes schematically the relationship between flexibility and nonflexibility in regulatory framework and its 
implications for users. Figure 1 depicts four stages of the regulatory framework in which flexibility is regarded in the context of "a true and fair view" of the company's accounts, flexibility which is serving preparers' interests (within creative accounting framework) and flexibility which goes beyond the regulatory framework often associated with fraud.

\begin{tabular}{|llll}
\hline $\begin{array}{l}\text { No } \\
\text { flexibility }\end{array}$ & $\begin{array}{l}\text { Flexibility to } \\
\text { give a 'true } \\
\text { and fair' view }\end{array}$ & $\begin{array}{l}\text { Flexibility to } \\
\text { give a creative } \\
\text { view }\end{array}$ & $\begin{array}{l}\text { Flexibility to } \\
\text { give a fraudulent } \\
\text { view }\end{array}$ \\
$\begin{array}{l}\text { Regulatory framework } \\
\text { eliminates accounting } \\
\text { choice }\end{array}$ & $\begin{array}{l}\text { Working within } \\
\text { regulatory framework } \\
\text { to serve users' } \\
\text { interests }\end{array}$ & $\begin{array}{l}\text { Working within } \\
\text { regulatory framework } \\
\text { to serve preparers' } \\
\text { interests }\end{array}$ & $\begin{array}{l}\text { Working outside } \\
\text { regulatory } \\
\text { framework }\end{array}$ \\
& Within regulatory framework & & Outside regulatory \\
framework
\end{tabular}

Figure 1. Flexibility within accounting

Source: Adapted from Jones (2011)

Accent is put on the fact that flexibility within regulatory framework is designed to serve the fundamental notion of "a true and fair view" of accounting books. However, in many cases it is being used to serve preparers' interests instead of interests of the external users of financial statements - investors, potential employees, government, banks, etc. $\mathrm{He}$ argues that if there is no flexibility within the regulatory framework, there will be no creative accounting, but there will be also no "true and fair view".

Even though most US authors perceive fraud as part of the creative accounting, while the UK researchers exclude fraud from the definition, for the purpose of this piece of research we will review creative accounting from UK perspective - excluding fraud.

\section{Definition of UN's sustainable development goals and how they are related with creative accounting}

UN General Assembly (2018) summarizes the sustainable development goals under the following definition: "The Sustainable
Development Goals are the blueprint to achieve a better and more sustainable future for all. They address the global challenges we face, including those related to poverty, inequality, climate, environmental degradation, prosperity, and peace and justice. The Goals interconnect and in order to leave no one behind, it is important that we achieve each goal and target by 2030".

\subsection{Review on the SDGs}

Seventeen SDGs and 169 indicators form a continuous basis for companies to create, enhance, inform and report on their strategies, objectives and activities. This will improve communication with key stakeholders, increase their loyalty and the transparency of the business environment and quality management as a framework for corporate sustainability in terms of growth of legal, reputational risk, volatility of financial markets and access to finance (United Nations Resolution, 2015, p.1).

Goal 1 stands for no poverty (United Nations Resolution, 2015, p.15) - the target is alleviation of extreme poverty of the 


\section{Articles}

population all over the world, referred to as people living on less than 1,25 USD a day.

Goal 2 stands for zero hunger. The basic objective of this goal is to ensure that all people, especially vulnerable groups, have access to safe, nutritious and sufficient food all year round.

Sustainable development goal 3 is aiming at good health and wellbeing all around the world.

Goal 4 stands for quality education and is aiming at free and quality access to education for all boys and girls, while SDG 5 is fighting for gender equality which means zero tolerance to women's discrimination all over the world and elimination of all kinds of violence against children. Involving women in the decision-making process on an equal basis with men is a top priority of the fifth goal's agenda.

A recent report published by Bath (2018) reveals the prominence of the 6th SDG ensuring access to water and sanitation for all. He accentuates on the fact how critical water is to our daily lives by presenting evidence on the ever-heightening water crisis in Cape Town. Numbers show that water deficiency affects more than 40 percent of the world and that figure continues to rise. It is expected that water shortages will affect 50 billion people by the year of 2050 .

Here is the moment to mention SDG 7 - Ensuring access to affordable, reliable, sustainable and modern energy because it is closely related with the issue of water and sanitation.

Along with the aforementioned, also the following SDGs came into force on 1 January 2016, which are part of the 2030 Agenda for Sustainable Development, adopted by the UN summit in September 2015 (United Nations Resolution, 2015, p.15): SDG 8 Decent work and economic growth; SDG 9 - Industry, innovation and infrastructure;
SDG 10 - Reduced inequalities; SDG 11 Sustainable cities and communities; SDG 12 - Responsible production and consumption; SDG 13 - Climate action; SDG 14 - Life below water; SDG 15 - Life on land; SDG 16 - Peace, justice and strong institutions; SDG 17 - Partnerships for the goals.

Goal 8 as stipulated in the Agenda, calls for "sustained, inclusive and sustainable economic growth, full and productive employment and decent work for all" (Rai, Brown and Ruwanpura, 2019, p. 368). They argue however, that even though labor rights for all are focus of the goal, some significant issues are identified. These are the gender balance and equal rights of men and women in the production of GDP.

A recent report of PwC (2016, p.3) emphasizes the importance of SDG 9 Industry, innovation and infrastructure. It accentuates on the adequate and stable infrastructure which is a basis for future economic growth and is the tool by which people access the resources needed for a high quality of life.

The significance of Goal 10 - Reduced inequalities is highlighted by World Bank Group (2019, p.2). The goal calls for "just, equitable, tolerant, open and socially inclusive world in which the needs of the most vulnerable are met". However, it faces lots of challenges. For example, the survey shows that even though significant advancement was made by Millenium Development goals, still large inequalities and disparities are evident in income and wealth, access to food, education, healthcare, clean water and other resources vital for living full and rewarding life.

MacDonald, Clarke, Huang, Roseland and Seitanidi (2018, p. 193) focus their attention on the relationship between SDG 11 - Sustainable cities and communities and SDG 17 - Partnerships for the goals. They argue that these two goals are interrelated 


\section{Articles}

so as multi stakeholder partnerships (SDG 17) are the basis for achievement of sustainable communities and cities (SDG 11). "Understanding the relationship between implementation structures and the outcomes is central to designing successful partnerships for sustainability", they say. The results of their study show that the partnership design is crucial to ensure progress on sustainability goals and to maintain partner engagement (p.205).

Goal 12 - Responsible production and consumption is critical to sustainable world (Tseng, Zhu, Sarkis, and Chiu, 2018, p.322). They argue that commerce, industry and business operations and strategies are decisive for the successful achievement of responsible production and consumption (RCP). RCP in turn can bring about sustainable consumption and production patterns in business by aiding energy and resource efficiency, quality infrastructure, and providing access to major services and green and decent jobs. Moreover, "RCP helps achieve overall sustainable development plans, reduce future economic, environmental and social costs, and strengthen economic competitiveness" (Tseng, Zhu, Sarkis, and Chiu, 2018, p. 323).

Lofts, Shamin, Zaman and Kibugi (2017, p.183) stipulate that SDG 13 - Climate action, commits governments to take urgent steps in preventing climate change and its impacts. Emphasis is placed on the agreed global need to decrease anthropogenic greenhouse gas emissions and to adapt to the harms already caused by climate change. The study is focused on the contributions made by the regulatory framework, international law and governance in achieving SGD 13, but also some core legal barriers are highlighted that the international community and the individual States confront in their endeavor to combat climate change and its effect.
Creative Accounting - Definition, Types, Purposes and Impact on United Nations' Sustainable Development Goals

PwC research (2016, p.2) pays attention to the vitality of Goal 14 - Life below water. Alarming statistics presented shows that 40 percent of oceans are affected by adverse human activity which results in pollution, depleted fisheries, and loss of coastal fauna. Land-based activities represent 80 90 percent of marine pollution. The numbers show that "the market value of marine and coastal resources and industries is estimated at 3 trillion USD per year or about 5 percent of global GDP". This is the reason why major role in sustainability policies in pollution prevention is given to the private sector. The focus is based on investment, innovation and connectivity practices among businesses to alleviate pollution and regulate harvesting, overfishing, destructive practices and implement science-based management plans (PwC, 2016, pp.3-4).

Achievement of Goal 15 - Life on land is vital to meet the challenges of protection, restoration and promotion of sustainable use of terrestrial ecosystems, sustainable management of forests, prevention of desertification and fend off land degradation and biodiversity loss (Scotdec, 2017). The land life preservation challenges are a lot, ranging from deforestation to species extinction. The outcomes of these are devastating - if forests are destroyed, the humankind will lose its ability to produce medicines, people will lose their homes, biodiversity will decrease, climate will change, etc.

Sustainable development cannot be realized without peace and security (HLPF, 2019, pp. 1-2). Furthermore, Goal 16 - Peace, justice and strong institutions - is recognized to be both an outcome and an enabler of sustainable development. It is also closely connected with the other SDGs. Achievement of other goals such as ending poverty, ensuring education, promotion of economic 


\section{Articles}

growth would be impossible without peace, justice and inclusion.

All these Goals are interconnected and most of the authors argue that without taking care of one of them, it is not possible to achieve
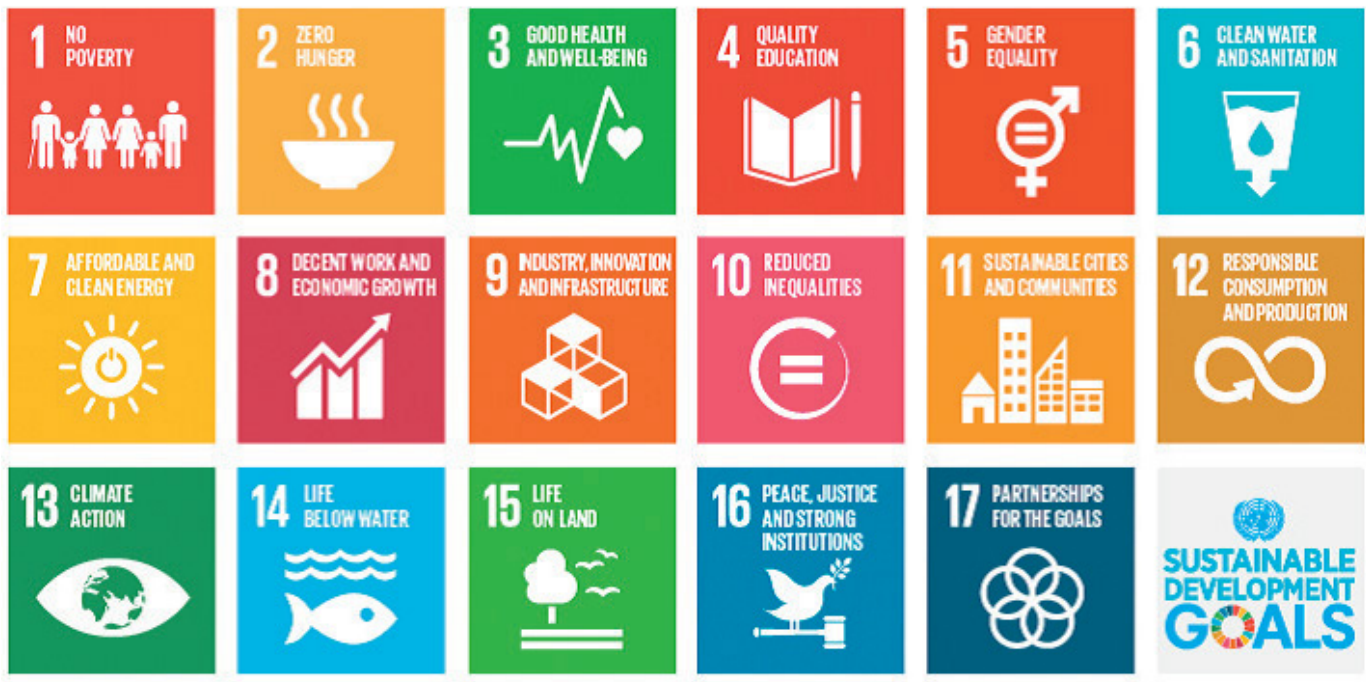

Source: The United Nations Sustainable Development Goals (SDGs)

\subsection{How accounting is related to and affects UN's sustainable development goals?}

The notion of Sustainable Development and specifically the Sustainable Development Goals impacted the metamorphosis in the business operations of the companies (Makarenko and Plastun, 2017, p.4). They accentuate how important is the role of professional accountants and illustrate the relevance of the Global Sustainable Development Goals set out at the UN Summit in New York in 2015. As opposed to the Millenium Development Goals, the SDGs are more focused on the active engagement of the business society, its investment and innovation capacity to deal with these challenges by transforming them into business priorities. PwC report (2015, p.9) shows that 71 percent of companies already took steps to implement the SDGs into their operations.
ACCA report (2017, p.10) underlines the role of professional accountants in delivering of 2030 SDGs. The report emphasizes on the skillsets, organizational role and ethical commitment of management accountants across the world and places members of the profession at the forefront of SDGs planning and implementation. The areas accounting professionals can influence range widely, from developing new courses of action, to documenting major successes, highlighting risk and proposing alternative courses of action.

On the Conference on Trade and Development International Standards of Accounting and Reporting (UNCTAD ISAR, 2015), IFAC President, Warren Allen, asserts how important accounting profession is for achieving seven out of the 17 sustainable development goals. He believes that professional accountants will contribute to 


\section{Articles}

achieving Objective 4 - Quality education, Objective 8 - Decent work and economic growth, Objective 9 - Industry, innovation, and infrastructure, Objective 12 - Responsible consumption and production, Objective 13 Climate action, Objective 16 Peace, justice, and strong institutions and Objective 17 Partnership for the goals.

Makarenko and Plastun (2017, p.6) argue that the most prominent SDGs for the accountants are the following: 12.6, 8.3, 17.16 and 17.18. Goal 12 and its target 12.6 act as a basis for the sustainable corporate development. They relate to incorporation of the sustainable development criteria into the mission, strategy, tactical decisions and operating policies of business. As a result, the demand for more transparent and quality sustainability reporting is growing. They illustrate how eight out of 17 SDGs and their 17 targets have direct relation to accounting. Accountants can influence their achievement
Creative Accounting - Definition, Types, Purposes and Impact on United Nations' Sustainable Development Goals

and at the same time transform accounting according to the new challenges from sustainable corporate development.

How important is the relationship between creative accounting and SDGs can be implied by reviewing the digital aspect of those two phenomena. Justenhoven, Loitz and Sechser (2018, p.25) review the importance of information and communication technology in accounting, showing how ERP systems are increasingly integrated by companies in Figure 3. The latter reveals the plans of the companies to change their ERP systems in near future by a survey carried out among sample of decision makers in 2018. Despite the slight decrease of 1 percent of the indicators in 2017 as compared to 2016, the conclusion of the report is that the majority of companies are not planning to change their ERP systems for financial accountability and this trend will be acknowledged in the next years.

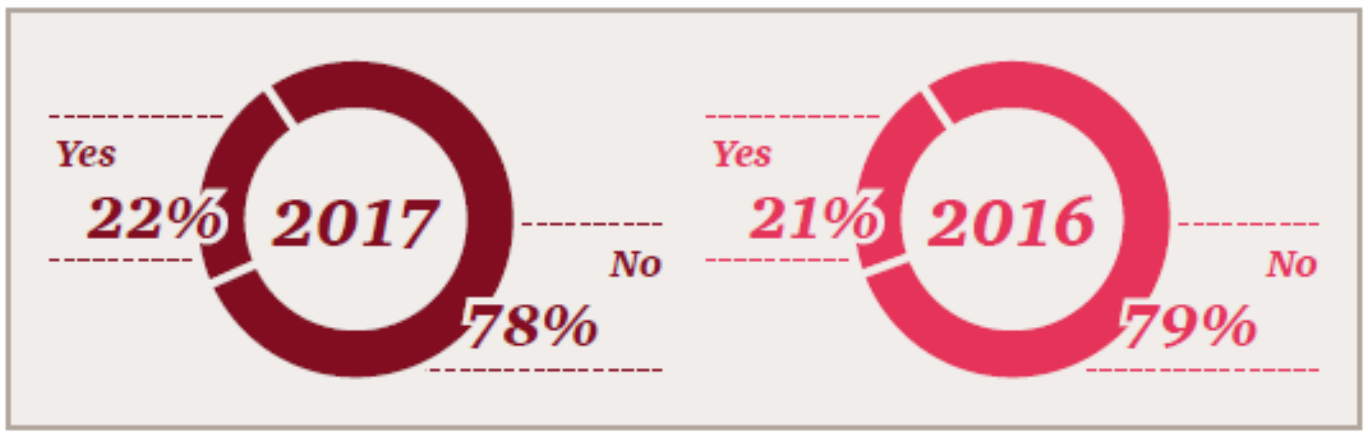

Figure 3.

Source: Justenhoven, Loitz and Sechser (2018). Digitalization in Finance and Accounting and what it means for financial statements audits.

On the other hand, the report is emphasizing on the plans of the companies to expand their ERP systems in the near future instead of changing them. The survey conducted by Justenhoven, Loitz and Sechser (2018, p.26) compares a sample of companies as at the end of 2016 and 2017 (see Figure 4). It is clearly visible that there is a two-percent growth of the companies planning to expand their ERP systems for higher quality reporting in 2017 as compared to 2016 and this trend will be sustained in the future. 


\section{Articles}

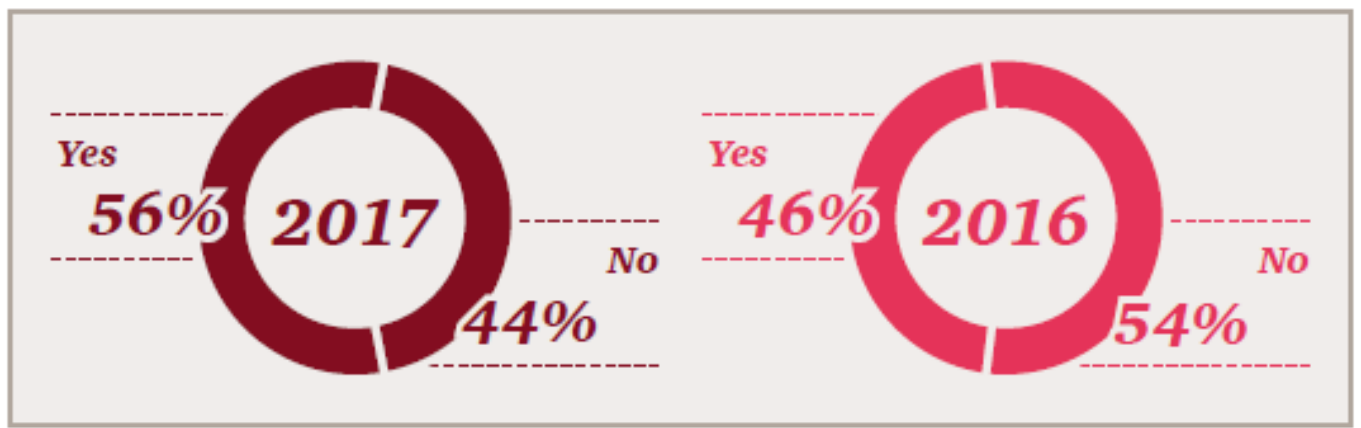

Figure 4.

Source: Justenhoven, Loitz and Sechser (2018). Digitalization in Finance and Accounting and what it means for financial statements audits.

The overall conclusion of the report of Justenhoven, Loitz and Sechser (2018) is that information technology and communication increases data quality, limits the deficiencies of financial reporting, delivers more powerful tools for accounting reliability and correctness and facilitates financial audits. This implies reduced possibilities for implementation of creative accounting techniques.

To emphasize the role of Information and Communication technologies in the delivery of 2030 SDGs, Wu, Guo, Huang, Liu and Xiang $(2018, p .1)$ argue that "although none of the 17 SDGs particularly refers to Information and Communications Technologies (ICTs), and only several targets mention ICTs and relevant technologies, the 2030 Agenda for Sustainable Development still claims that the ICTs can substantially accelerate the development progress of human beings, and may greatly bridge the digital gaps, so as to construct knowledge communities". This paper reveals how important are the ICTs for achievement of each of the 17 SGDs and their 169 sub-targets. Furthermore, it identifies key gaps between ICTs and SDGs which requires collaboration amongst researchers of different disciplines and extensive cooperation and communication between governments, industry, NGOs and institutions. Appendix 1 illustrates schematically the relationship between ICTs and 6 out of 17 of the SDGs: Goal 6 - Cleaner water and sanitation, Goal 7 - Affordable and clean energy, Goal 12 Responsible consumption and production, Goal 13 - Climate action, Goal 14 - Life below water and Goal 15 - Life on land.

Wu, Guo, Huang, Liu and Xiang (2018, p.1) and Justenhoven, Loitz and Sechser (2018) both illustrate the critical role of ICTs in the prevention of creative accounting and in the delivery of 2030 SDGs and indirectly identify a close relationship between those two phenomena. The first one - creative accounting, is largely dependent on ICTs in terms of its prevention which means more quality financial results and positive impact on the delivery of 2030 SGDs. On the other hand, wide implementation and integration of ICTs in each of the 17 goals and their 169 sub-targets will assure their quality, timely, effective and large-scale delivery.

Another prominent study examining ICTs and specifically big data was carried out by Wu, Guo, Li and Zeng (2016). To confirm the postulates in previous paragraphs, we pay special attention to the challenges in processing huge amounts of data, big data, and how to tackle problems like environmental concerns and sustainability. Their study is essential to the topic of delivery of 2030 SDGs, because it examines the relationship between 


\section{Articles}

big data and green metrics and suggests two new approaches - effective energy efficiency and effective resource efficiency in order to meet new challenges and bring innovative views in green metrics. How to "green" big data systems is a major objective of their study and essential contribution in the literature on the topic. The concept of "greening" big data is illustrated schematically in Appendix 2.

\section{How creative accounting negatively affects UN's sustainable development goals?}

In the previous section we identified the relationship between accounting and SDGs and how accounting can affect those positively. For the purpose of our research however, we need to establish what is the negative effect of accounting on the achievement of the SDGs and how vicious accounting practices adversely affect society and the SDGs in particular. To achieve this, we need to answer the following questions: What happens when professional accountants are engaged in creative accounting practices? How do these engagements prevent the achievement of the SDGs?

To get insight on these questions some literature research and empirical examples are presented to identify the symmetric correlation between these two phenomena. Financing the SDGs is one of the benchmarks of their eventual achievement. Weber (2018, p.3) emphasizes on the fact that there is an investment gap in developing countries amounting to 2.5 trillion USD. Generally, between 5 and 7 trillion USD will be required annually until 2030 to achieve the SDGs. The domestic governments will cover the major portion of these expenses (between 50 and 80 percent), according to the estimations of the World Bank. Du Toit, Aniket Shah and Wilson (2017, p. 5) point out that the global economic output (gross world product) in 2015 was 113
Creative Accounting - Definition, Types, Purposes and Impact on United Nations' Sustainable Development Goals

USD trillion (purchasing power parity (PPP)), and is growing by approximately 3 percent in real terms per annum and the value of global financial assets is more than 290 trillion USD, with a growth rate of five percent per year. Compared to these figures, the 5 to 7 trillion USD needed for achievement of the SDGs does not look that big.

Addis Ababa Action Agenda (2015, pp.1051) sets out the "financing for development" priorities. The document is created as a result of the establishment of the new cycle of SDGs until 2030 and provides guidelines how SDGs will be funded. Five layers of funding opportunities are set out in the agenda. They are based mostly on government policies concerning the fair allocation of public resources. The Agenda aims to achieve sustainable fiscal policies on domestic level as a portion of the domestic public resources are intended to finance the SDGs. Sustainable fiscal policies, transparent and democratic institutions, corruption prevention at all levels are vital elements of the Agenda. In addition, it attributes a prominent role of the domestic and international private business sector to fund the SDGs as they are major drivers of economic growth, job creation and productivity.

Creative accounting in the private sector however, prevents the achievement of SDGs as it produces misleading financial information leading to payment of lower or no taxes which obstruct governments from allocation of the necessary portion of the domestic governments' income for financing of SDGs. Furthermore, when managers engage in accounts manipulations, they usually represent the balance sheet/cash accounts/earnings of a company to look favorable to investors. In most cases this is expressed in the risk perception of the market participants manifested by earnings per share and the debt/equity ratio (Breton and Stolowy, 
2000, p.3). Rani, Hussain and Chand (2013, p. 24) indicate two major incentives for accounts manipulations: to encourage investors to purchase company's shares and to augment the market value of the firm. This may lead to investors placing their funds in companies with poor performance in the market instead in such with sustainable indicators which do not use accounting manipulation practices. The outcome is failure of achievement of the second area of financing the SDGs set out in the Agenda - funding the SDGs by domestic and international private business and finance. Investors will place their funds in companies that will later go bankrupt, which will lead to failure to meet the job creation, investment, innovation and productivity targets set out by the Agenda.

Regarding the public sector, basic stimulus for usage of creative accounting is the presence of budgetary and fiscal regulations that forbid expenses exceeding a specific threshold set by an external body or a higher organization in the public administrative hierarchy (Cardoso and Fajardo, 2014, pp.17-18). The latter argue that monitoring authorities are the most cheated users of such information. They accentuate that majority of the literature on the public sector creative accounting focuses on European Union member states manipulating financial reports to comply with the Maastricht Treaty thresholds. On the other hand, Addis Ababa Action Agenda (2015, pp. 20-34) stipulates the importance of the domestic public resources for funding the delivery of SDGs. This includes focus on environmental, economic and social policies, sustainable fiscal policies, good governance, transparency of institutions, combat against corruption and prominence of the rule of law. The contradiction between the stipulated Agenda and the public sector manipulations may lead to failure in meeting the targets of the Agenda and public bodies reporting more favorable figures, thus failing to allocate the required portion of the national budget for delivery of SDGs.

Additionally, some countries which fall within the vulnerable target group of the Agenda may take advantage of their vulnerability, reporting more unfavorable figures of their economies in order to receive higher funding as opposed to countries within the same target group. All of these practices break down the confidence in the governmental institutions and prevent the achievement of feasible, inclusive and sustainable economic growth (SDG 8). Failure to deliver resilient business environment in domestic countries will prevent foreign investors from placing their funds in national economies which are engaged in creative accounting. This will again lead to failure in meeting the productivity, inclusive economic growth and job creation targets which are put at the forefront in Addis Ababa Action Agenda (2015, p.17).

\section{Conclusion, recommendations and future research on the problem}

This article does not claim comprehensiveness as due to the lack of appropriate empirical data evidencing the negative impact of the creative accounting over the achievement of SDGs, only literature reviews and practical examples were shown and discussed and inferences were made based on those reviews. Most of the literature is focused on the positive impact professional accountants may have on the achievement of SDGs, but on the negative side of the coin there is still lack of sufficient and convincing evidence. Nevertheless, this article identified some critical points of intersection between these two phenomena and direct relationship between creative accounting practices and action areas of funding the SDGs stipulated in Addis Ababa Action Agenda (2015). This 


\section{Articles}

will be a benchmark for future research on the problem.

\section{References}

ACCA, 2017. The Sustainable Development Goals: redefining context, risk and opportunity. Retrieved from: https://www.accaglobal.com/ content/dam/ACCA_Global/professionalinsights/The-sustainable-development-goals/ pi-sdgs-accountancy-profession.pdf

Adis Abeba Action Agenda, 2015. Financing for Development. Third international Conference on Financing for Development. Adis Abeba, Ethiopia: United Nations. Retrieved from: https://www.un.org/esa/ffd/wp-content/ uploads/2015/08/AAAA_Outcome.pdf

Allen, W., 2015. UNCTAD ISAR. The Accountancy Profession and the Sustainable Development Goals. Geneva, Switzerland: UNCTAD ISAR. Retrieved from: https://www. ifac.org/news-events/2015-11/accountancyprofession-and-sustainable-developmentgoals

Bath, S., 2018. Ensuring Access to Water and Sanitation for All: What SDG 6 wants to achieve and why it matters. Many of us take water-the world's most essential elementfor granted. Canada: IISD. Retrieved from: https://www.iisd.org/blog/ensuring-accesswater-and-sanitation-all-what-sdg-6-wantsachieve-and-why-it-matters

Bragg, S., 2018. USA: AccountingTools ACCOUNTING CPE COURSES \& BOOKS Creative Accounting. Retrieved from: https:// www.accountingtools.com/articles/2017/5/14/ creative-accounting

Breton, G. and Stolowy, H., 2000. A framework for the classification of accounts manipulations. Paris: HEC Accounting \& Management Control Department. Retrieved from: https://papers.ssrn.com/sol3/papers. cfm?abstract_id=263290

Cardoso, R and Fajardo, B., 2014. Public Sector Creative Accounting: a literature
Creative Accounting - Definition, Types, Purposes and

Impact on United Nations' Sustainable Development Goals

review. Retrieved from: https://papers.ssrn. com/sol3/papers.cfm?abstract_id=2476593

CIMA Official Terminology, 2005. The Chartered Institute of Management Accountants. London: CIMA Publishing.

Du Toit, H., Shah, A. and Wilson, M., 2017. Ideas for action for a long term and sustainable financial system. A paper commissioned by the Business and Sustainable Development Commission. Retrieved from: http:// s3.amazonaws.com/aws-bsdc/BSDC_ SustainableFinanceSystem.pdf

HLPF (High-Level Political Forum on Sustainable Development, 2019). 2019 HLPF review of SDG implementation: SDG 16 Promoting peaceful and inclusive societies for sustainable development, providing access to justice for all, and building effective, accountable and inclusive institutions at all levels. Retrieved from: https:// sustainabledevelopment.un.org/content/ documents/23672BN_SDG16_LV.pdf

Jones, M., 2011. Chapter 1: Introduction Setting the Scene. In M. Jones (ed.). Creative Accounting, Fraud and International Accounting Scandals (1 ${ }^{\text {st }}$ ed., pp. 3-18), England: John Wiley\&Sons Ltd, The Atrium, Southern Gate, Chichester.

Justenhoven, Loitz and Sechser, 2018. Digitalization in Finance and Accounting and what it means for financial statements audits. PwC. Retrieved from: https://www.pwc.de/ de/im-fokus/digitale-abschlusspruefung/pwcdigitalisation-in-finance-2018.pdf

Lofts, K., Shamin, S., Zaman, S. and Kibugi, R., 2017. Feature - Brief on Sustainable Development Goal 13 on Taking Action on Climate Change and Its Impacts: Contributions of International Law, Policy and Governance. Retrieved from: https://www.mcgill.ca/mjsdl/ files/mjsdl/issue_brief_final_march_30.pdf

MacDonald, A., Clarke, A., Huang, L., Roseland, M. and Seitanidi, M., 2018. Multi stakeholder Partnerships (SDG \#17) as a 


\section{Articles}

Means of Achieving Sustainable Communities and Cities (SDG \#11). Springer International Publishing AG 2018. Retrieved from: https:// www.uwaterloo.ca/scholar/sites/ca.scholar/ files/acclarke/files/2018_Clarke_Macdonald_ SDG17_SDG11.pdf

Makarenko, I., and Plastun A., 2017. The role of accounting in sustainable development. Ukraine: Accounting and Financial Control, 1(2), 4-12.

Oyedokun, G., 2018. Any justification for creative accounting: Where are fraud examiners? ACFE African Conference October 15-17, 2018: Johannesburg. Keffi, Nigeria. OGE Professional Services Ltd; Nasarawa State University. Retrieved from: https://papers.ssrn.com/sol3/papers. cfm?abstract_id=3272415

PwC, 2015. Make It Your Business: Engaging with Sustainable Development Goals. Retrieved from: https://preview.thenewsmarket.com/Previews/PWC/DocumentAssets/401355.pdf

PwC, 2016. SDG 9: Industry, innovation and infrastructure. Build resilient infrastructure, promote inclusive and sustainable industrialisation and foster innovation. Retrieved from: https://www.pwc.com/mu/en/events/ CRA2019/cragoals/Goal9.pdf

PwC, 2016. SDG 14: Life below water. Conserve and sustainably use the oceans, seas and marine resources for sustainable development. Retrieved from: https://www. pwc.com/mu/en/events/CRA2019/cragoals/ Goal14.pdf

Rai, S., Brown, B., Ruwanpura, K., 2019. SDG 8: Decent work and economic growth - A gendered analysis. World Development 113 (2019) 368-380.

Rani, P., Hussain, F., and Chand, P., 2013. Managerial Incentives for Earnings Management Among Listed Firms: Evidence from Fiji. Global Journal of Business Research, 7(1), 21-31.
Scotdec, 2017. Goal 15: Life on land Protect, restore and promote sustainable use of terrestrial ecosystems, sustainably manage forests, combat desertification, and halt and reverse land degradation and halt biodiversity loss. Retrieved from: https://www.scouts.scot/ media/1606/goal-15-life-on-land.pdf

Tseng, M., Zhu, Q., Sarkis, J. and Chiu, A., 2018. "Responsible consumption and production (RCP) in corporate decisionmaking models using soft computation", Industrial Management \& Data Systems, Vol. 118 No. 2, pp. 322-329.

UNCTAD ISAR, 2015. The Accountancy Profession and the Sustainable Development Goals. Switzerland: UNCTAD ISAR Geneva. Retrieved from: https://www.ifac.org/newsevents/2015-11/accountancy-profession-andsustainable-development-goals

United Nations, 2019. High level political forum on sustainable development: 2019 HLPF review of SDG implementation: SDG 16 Promoting peaceful and inclusive societies for sustainable development, providing access to justice for all, and building effective, accountable and inclusive institutions at all levels. Retrieved from: https:// sustainabledevelopment.un.org/content/ documents/23672BN_SDG16_LV.pdf

UN General Assembly, 2018. About the Sustainable Development Goals. United Nations. Retrieved from: https://www.un.org/ sustainabledevelopment/sustainabledevelopment-goals/

United Nations Resolution, 2015. Resolution adopted by the General Assembly on 25 September 2015. Transforming our world: the 2030 Agenda for Sustainable Development. Retrieved from: http://www.un.org/ga/search/ view_doc.asp?symbol=A/RES/70/1\&Lang $=E$

Weber, O. (2018). The Financial Sector and the SDGs. Interconnections and Future Directions. Ontario, Canada: Center of Governance and Innovation. CIGI Papers 


\section{Articles}

No. 201 - November 2018. Retrieved from: https://www.cigionline.org/sites/default/files/ documents/Paper\%20No.201web.pdf

World Bank Group, 2019. Sustainable Development Goal 10 - Reduced Inequalities: Progress and Prospects. An Expert Group Meeting in preparation for HLPF 2019: Empowering people and ensuring inclusiveness and equality. Geneva, 2-3 April 2019. Retrieved from: https:// sustainabledevelopment.un.org/content/
Creative Accounting - Definition, Types, Purposes and Impact on United Nations' Sustainable Development Goals

APPENDICES:

\section{Appendix 1 - The ICTs based architecture to promote the environmental SDGs.}

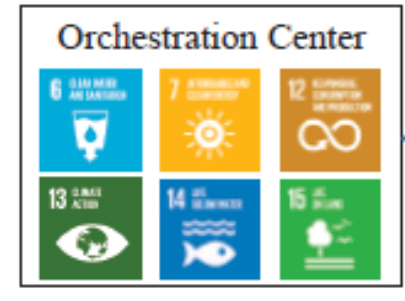

Edge computing \& Fog computing

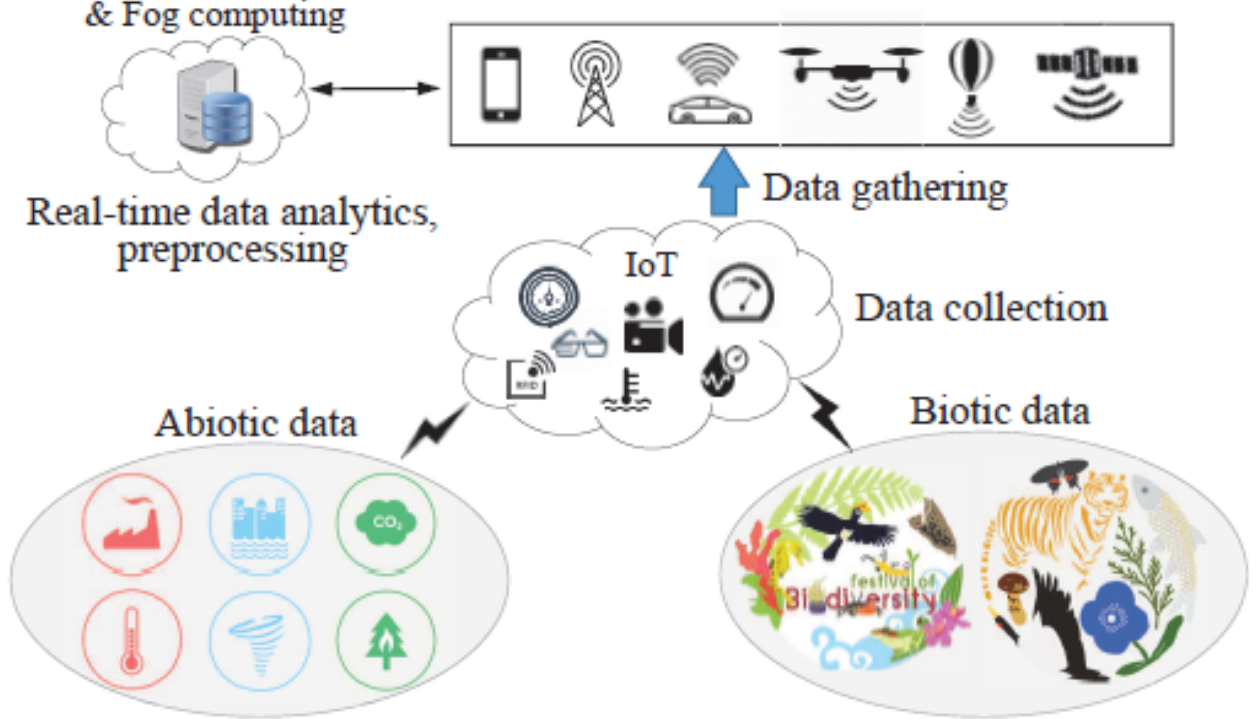

Source: Wu, J., Guo, S., Huang, H., Liu, W. and Xiang, Y. (2018). Information and Communications Technologies for Sustainable Development Goals: State-of the-Art, Needs and Perspectives. Retrieved from: https://arxiv.org/ pdf/1802.09345.pdf 
Articles

2. Appendix 2 - Greening big data:

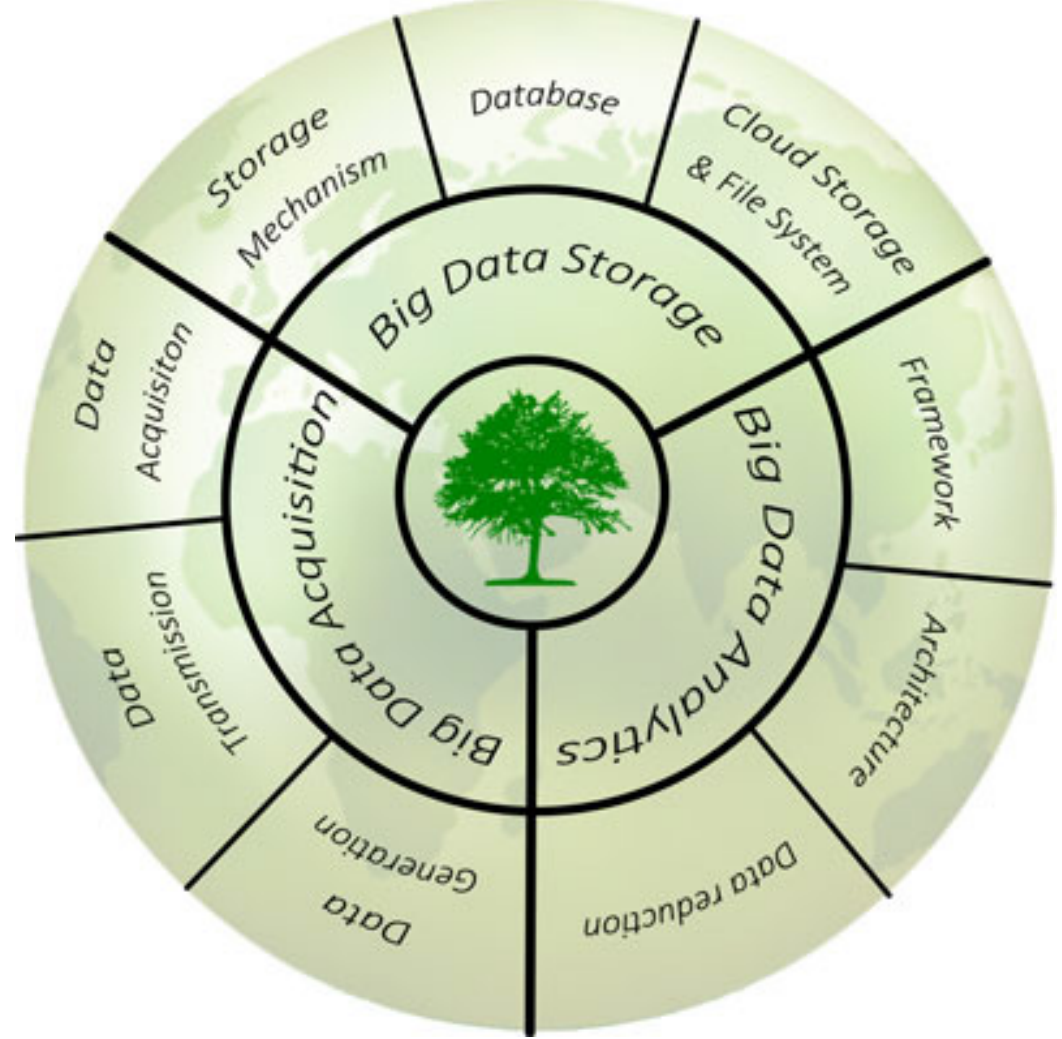

Source: Wu, J., Guo, S., Li, J. and Zeng, D. (2016). Big Data Meet Green Challenges: Greening Big Data. IEEE Systems Journal, vol. 10, NO. 3. 